\title{
Infectious Bronchitis Virus in Asia, Africa, Australia and Latin America - History, Current Situation and Control Measures
}

Workshop: Infectious Bronchitis (IB) in the Brazilian Poultry Industry

\section{Author(s)}

Wit JJ (Sjaak) de

Cook JKA ${ }^{2}$

van der Heijden HMJF

GD (Animal Health Service), P.O.B. 9, 7400 $A A$, Deventer, The Netherlands.

138 Hartford Road, Huntingdon, Cambs. PE29 1XQ, UK.

Mail Address

Dr J.J. (Sjaak) de Wit

Immunoloog

GD, Postbus 9, 7400 AA Deventer

Phone: 0900-1770

Direct: 0570-66 0178

Mobiel: 06-511 59794

E-mail: j.d.wit@gddeventer.com

Keywords

Control, infectious bronchitis virus, history, variants.

\section{ABSTRACT}

\section{INTRODUCTION}

Infectious bronchitis virus (IBV) is ubiquitous in most parts of the world where poultry are reared and is able to spread very rapidly in nonprotected birds. It is shed via both the respiratory tract and the faeces and can persist in the birds and faeces for several weeks or months. Although strict biosecurity and working with a one-age system are essential control measures, normally vaccination is an essential tool to increase the resistance of the chickens against challenge with IBV strains. This paper presents an overview of the history and current situation of IBV in Asia, Africa, Australia and Latin America, including the control measures necessary to control it.

\section{HISTORY OF INFECTIOUS BRONCHITIS VARIANTS}

For many years it was widely believed that the first variants of infectious bronchitis virus (IBV) occurred in the early 1950s as Jungherr et al. (1956) in the USA showed that the Connecticut (Conn) isolate of 1951 neither cross neutralised nor cross protected with the original Massachusetts (Mass) isolate from the early 1940s. However, a retrospective study (Jia et al., 2002), using monoclonal antibodies and molecular analysis of part of the $\mathrm{S} 1$ subunit of the spike glycoprotein (S) gene, identified non-Mass IBVs among US isolates as early as the 1940s. Since the 1950s there have been many reports of other IB variants in USA (reviewed by Fabricant, 1998), some of which are found worldwide. However, most countries are now known to have their own indigenous variants as well, and this paper will consider the situation outside USA and Europe.

IBV appeared in Latin America by the 1950s and the first reported isolate from that continent was of the Mass serotype in Brazil (Hipólito, 1957), although isolation of the first variant (Arkansas [Ark]) was not reported in that county until some 10 years later (Branden \& Da Silva, 1986). In a study carried out in the mid 1990s, IB isolates of at least 5 different antigenic types were found in commercial chickens of all types throughout Brazil, but mainly in the major poultry producing area of the south (Di Fabio et al., 2000). More recently, several different genotypes have been identified in Brazil by analysis of either the S1 (Villarreal et al., 2007a; Villarreal et al., 2007b; Montassier et al., 2008) or the nucleoprotein $(\mathrm{N})$ genes (Abreu et al., 2006), but protection studies have not been performed. It is important to remember that in Brazil at that time, as in most other parts of the world, the only live attenuated IB vaccines licensed for use were of the Mass serotype and protection 
studies (Cook et al., 1999; Di Fabio et al., 2000) showed that the currently available Mass vaccine provided inadequate protection against some of these new variants. Hidalgo et al. (1976) reported the first isolation of IB (Mass serotype) in Chile in 1975 and variants were reported for the first time there some 10 years later (Hidalgo et al., 1986). By the mid 1980s, Infectious Bronchitis (IB) was reported as a serious problem in commercial chicken flocks and novel variants, as well as the Mass and Conn serotypes, were isolated from broiler and layer flocks and again, Mass vaccines were found to provide poor protection against challenge with these variants (Cubillos et al., 1991). Elsewhere in Latin America a variant IB was isolated from commercial chickens in Honduras in 1997 and poor protection against it using Mass vaccines was demonstrated (Cook et al., 1999). Following the isolation of the Ark serotype in Mexico in the early 1990s, the use of molecular methods then identified IB variants unique to that country in commercial chickens (Escorcia et al., 2000; Callison et al., 2001; Gelb et al., 2001). They were shown by neutralisation tests to be different from Mass or Conn serotypes, but in vivo protection studies were not performed. Rather surprisingly, IBV variants do not appear to have been reported in Argentina until very recently, when Rimondi et al. (2009), using only molecular techniques, detected 3 unique genotype clusters (in addition to Mass and Conn), one of which was closely related to isolates from Brazil. Similar techniques had been used a few years earlier to identify for the first time a genetically unique IB variant in Colombia (Alvarado et al., 2005).

An IBV associated with swollen head syndrome and causing severe problems throughout southern Africa was isolated in the early 1980s (Morley \& Thomson, 1984), confirmed as a variant, and shown to be poorly protected against by Mass vaccines (Cook et al., 1999). The only other report of the detection of IBV variants in sub-Saharan Africa is the recent report by Ducatez et al. (2009), who detected a novel IBV in Nigeria and Niger, antigenically and genetically distinct from other known IBVs. However, no association with disease was demonstrated and there is no information on the ability of currently available vaccines to protect against it.

IB variants have been recognised in Egypt since the 1950s (Sheble et al., 1986; Eid, 1998) with the isolation of an IB variant shown by neutralisation tests to be closely related to the Dutch variant D3128 and subsequently variants related to Mass, other Europeans IBVs and one related to an Israeli variant have been identified by genome analysis in that country (Abdel-Moneim et al., 2006). In the early 1980s the unusual enterotropic variant, know as IB "G" was isolated in Morocco (El-Houadfi \& Jones, 1985). More recently, Bourogaa et al. (2009) used both molecular methods and cross neutralisation tests to identify as variants IB isolates from Tunisia, which are closely related to ones found in Europe.

Variant IBVs have been recognised in Israel since at least the mid 1990s (Meir et al., 1998; Callison et al., 2001; Meir et al., 2004) on the basis of both virus neutralisation tests and molecular techniques, and protection studies have shown that Mass vaccines provide inadequate protection against some of these novel variants. In Jordan, the use of RT-PCR enabled European IB variants D274 and 4/91 (793B) to be detected (Roussan et al., 2008), but since the primers used were designed to detect only specific variants, it is possible that others are present in that country. Similar methods have been used to identify 4/91 in Iran (Seyfi Abad Shapouri et al., 2004).

In the Indian subcontinent, antibodies to several "American" (Muneer et al., 1987a) and "European" (Ahmed et al., 2007) IB variants have been demonstrated in Pakistan, but virological studies have still to be performed. An IBV isolated in India in the early 2000s from cases of nephrosis, was reported to have a unique $\mathrm{S} 1$ sequence, indicating it to be different from other known IBVs (Bayry et al., 2005).

In Asia, many studies have been performed in different countries in recent years. In Malaysia where IBV was first isolated in 1967, variants have been present since at least 1979 (reported by Lohr, (1988). More recently, molecular epidemiological studies of IBVS isolated in Malaysia and Singapore showed that, whilst some were of the Mass serotype (probably identical to the $\mathrm{H} 120$ vaccine), others were similar to IBVs reported from China and Taiwan (Yu et al., 2001). These studies led the authors to suggest that IB variants have existed in Asia for some time. This finding was substantiated by Zulperi et al. (2009) who used sequence and phylogenetic analysis to study two variants isolated in Malaysia, 10 years apart. One was similar to several Chinese variants whilst the other was characterised as unique to Malaysia, but no protection studies were performed. IB has been a problem in Thailand since the 1950s, despite the use of many different IB vaccines and a recent molecular study by Pohuang et al. (2009) has identified two groups of IB variants in Thailand by phylogenetic analysis of the SI gene. Group I appeared to be unique to that country, whilst Group II showed a 
close relationship to Chinese IBVs, including variant A2 (see below).

IB variants have been associated with disease outbreaks in Korea since at least the mid 1980s (Song et al., 1998). Initially, Mass vaccines were successful in controlling disease, but since 1990 IB outbreaks have been experienced in well-vaccinated flocks with an increased incidence of renal problems. Song et al. (1998) classified 40 IB isolates as Mass plus four local genotypes, one of which was not only the predominant type, but in pathogenicity studies, it caused $50 \%$ mortality in SPF chicks inoculated at day-old. More recent studies (Lee et al., 2004) have extended this work and reported further genetic diversity amongst Korean IB variants isolated from diseased flocks; some of which are indigenous to Korea, whilst others share genetic relationships to IB variants from other countries in the region (Lee et al., 2008). It is suggested that Korean IBVs are continually evolving (Jang et al., 2007).

Mase et al. (2004) carried out a detailed analysis of Japanese IB variants by looking at the $\mathrm{N}$-terminus of the $\mathrm{S} 1$ glycoprotein and identified three major genetic groups not found in other countries. One group, present in Japan since at least the 1960s, may be found only in Japan, whilst the other two, which are more recent, are related to Chinese and Taiwanese variants (see below). These groups were distinct from those found in Europe or USA. However, the 4/91 serotype has recently been isolated in Japan (Mase et al., 2008; Shimazaki et al., 2008).

IB variants have been recognised in Taiwan since at least the mid 1960s and two distinct lineages have been identified, as well as Mass and IBVs related to those reported in neighbouring countries (Wang \& Tsai, 1996; Wang \& Huang, 2000; Huang et al., 2004). The failure of Mass vaccines to provide adequate protection led to the development of vaccines from indigenous strains (Huang \& Wang, 2006).

For many years little was known of the situation regarding IB variants in China, but the fact that Mass type vaccines were used successfully suggests that variants may not have been a problem before the 1980s. However, by the mid 1990s, this was clearly no longer that case and in the last decade many published reports have revealed the diversity of IBVs causing disease in that country. By means of in vivo studies and antigenic typing using monoclonal antibodies and cross-neutralisation tests, Wu et al. (1998) identified highly pathogenic IBV variants in China associated both with respiratory disease and nephritis, and showed that the $\mathrm{H} 120$ vaccine provided poor protection against the challenge with these isolates. In a recent study of 26 IBVs isolated between 1985 and 2008 from a variety of disease conditions in the Guangxi region of China, Wei et al. (2009) identified 4 clusters based on RT-PCR analysis of the $\mathrm{N}$ gene. They were grouped into 7 serotypes by neutralisation tests, but there was poor correlation between the results of genotyping and serotyping. In an analysis of the genome of 26 IB variants isolated from kidneys, proventriculus, and oviduct in different areas of China between 1995 and 2004, Liu et al. (2006) identified Mass type IBVs plus five genotypes apparently found only in China and cocirculating there. One of these (genotype A2) was subsequently shown to be the dominant indigenous type in China (Liu et al., 2009). Other genotypes showed close relationships with either Korean or Taiwanese IB variants, and one was closely related to an Australian isolate (Liu et al., 2006). Cuiping et al. (2007) identified the 4/91 variant in China, along with the Australian $T$ strain, as well as one variant indigenous to China. Thus the diversity of IB variants in China is now well established, some being restricted to and co-circulating in that country, whilst others show similarities with IB variants identified in other countries in that region.

Molecular characterization using a part of the $S$ gene of 91 IBV strains isolated between 1998 and 2002 from chickens in Russia showed the complexity of the Russian IBV situation (Bochkov et al., 2006). The main group of isolates (38 viruses) belonged to the Mass genotype circulating in Russia since the early 1970s. A second group of 22 strains were of known European genotypes D274, 4/91, B1648, 624/I and Italy-02. Two isolates from very distant geographic locations in Russia (Far East and the European part) clustered together with Chinese strains of the QXIBV genotype. The remaining 27 Russian isolates were divided in 11 novel genotypes.

In Australia, where IBV has always evolved independently from the rest of the world due to its geographical isolation (Ignjatovic et al., 2006), many different IB variants have been isolated and characterised since the early 1960s (Cumming, 1963), and in vivo protection studies were performed with these variants (Klieve \& Cumming, 1988). Using both monoclonal antibodies directed against the major IBV proteins and sequencing studies, several distinct lineages have now been recognised (Ignjatovic et al., 1997; Ignjatovic et al., 2006), all different from those found elsewhere. Interestingly, in the nearby country of New Zealand, IB problems were uncommon before 
the 1970s, when IB variants were first reported (Lohr, 1988). It was initially believed, using cross-neutralisation tests, that IB variants had evolved independently of those reported in Australia or US, and at least 4 different variants were identified (Lohr, 1976, 1977). However, sequencing of the S1 gene has recently revealed genetic relationships between these early IB isolates and ones made since 2000, and phylogenetic analysis also showed that they are more closely related to Australian than to European or North American isolates (McFarlane \& Verma, 2008).

The above account highlights the large number of $\mathrm{IB}$ variants that exist worldwide; some being unique to a particular area; others having a more general distribution. The origin of these variants is not clear, but Shieh et al. (2004), reporting the close relationship of isolates from Taiwan and Japan to IBVs found in Australia and USA, suggested that the Asian variants are recombinants; their $S$ gene being derived from Australian variants and the $\mathrm{N}$ genes from US strains.

\section{CURRENT SITUATION}

As discussed, it is becoming clearer that many countries have to deal with many types of IBV. At the moment genotyping is by far the most used system and has largely replaced serotyping and protectotyping. Does this create a problem? The preferred typing system depends on the goal (e.g. selection of vaccination programmes, or epidemiological studies), available techniques, experience, field situation and costs.

Classification systems are divided into two major groups: functional tests, that regard the biological function of a virus, and non-functional tests, that look at the viral genome (De Wit, 2000). Typing by functional tests results in protectotypes and antigenic types (serotypes and epitope-types). Tests that look at the genome result in genotypes. With protectotyping, the complete immune response of a chicken against an IBV strain is measured. For the field, grouping of IBV strains into protectotypes is the most important system from a practical point of view, because it provides direct information about the efficacy of a vaccine. Strains that induce protection in chickens against each other belong to the same protectotype. Protectotyping is laborious and expensive, and requires high level facilities for performing vaccination-challenge studies and SPF birds.

Serotyping is based on the reaction between an IBV strain and chicken-induced IBV serotype-specific antibodies. Two strains ( $A$ and $B$ ) are considered to be of the same serotype when two-way heterologous neutralisation titres (antiserum $A$ with virus $B$, and antiserum $B$ with virus $A$ ) differ less than 20 -fold from the homologous titres (antiserum $A$ with virus $A$, antiserum $B$ with virus $B$ ) in both directions (Hesselink, 1991). Serotyping becomes less practical when more IBV types are detected in a certain area, as every serotype needs its own neutralization test. For new strains that appear to be different, an antiserum has to be produced in SPF birds. As mentioned before, more and more countries have to deal with an increasing number of variants, which decreases the practicability of serotyping.

Grouping of strains based on genetic characterisation of (a part of) the genome results in genotypes. Methods include sequencing, detection of genotype-specific parts of the genome by RT-PCR, or determination of the position of enzyme cleavage sites (De Wit, 2000). Genomic information is objective and provides essential information for epidemiological studies. The part of the gene that encodes the S1 subunit of the spike glycoprotein is most frequetly used for genotyping. The $\mathrm{S} 1$ subunit of the $\mathrm{S}$ protein is the main inducer of protective immunity and carries most of the virus neutralizing epitopes, including serotypespecific epitopes, which are usually conformationdependent (Mockett et al., 1984; Cavanagh \& Davis, 1986; Koch et al., 1990; Cavanagh et al., 1992). A change of a few (percentage of) amino acids in the $\mathrm{S1}$ protein can already result in a change of serotype (Cavanagh et al., 1992) due to a change in a virusneutralizing epitopes, whereas other larger percentages of mutations at other parts of S1 might not result in relevant change in antigenicity of the virus. On the other hand, IB viruses of different serotypes and genotypes not only have different epitopes, but also share common epitopes, which are of importance in cross-immunity (Cavanagh et al., 1992; Cavanagh et al., 1997) and cell-mediated immune responses (Boots et al., 1992; Ignjatovic \& Galli, 1995). These aspects of the IB virus result in a disadvantage of the use of genotyping in the field, as the direct translation of information about usually of a part of the genome (usually a part of the $S$ gene) of an IBV strain into biological function or antigenicity of the virus is not possible or is not without risk. Despite these limitations, a few papers have reported that the S1 gene sequence (part of 700 nucleotides) comparison was a better predictor of immune challenge in chickens than serotyping by virus neutralization (Ladman et al., 2006). 
Whether this is a general rule is unknown, as only a small number of strains and vaccines have been compared, and also different parts of the $\mathrm{S} 1$ gene were used for the comparison of the homology. But in general, a lower homology in the sequence of the S1 subunit of 2 strains (e.g. a vaccine and a field strain) means that there is more chance that relevant mutations have occurred, what might result in a lower cross-protection.

An analysis of several papers reporting the level of homology of the $\mathrm{S} 1$ gene or a part of it and the level of cross-protection (Cavanagh et al., 1997; Cook et al., 2001; Meir et al., 2004; Gelb et al., 2005; Ladman et al., 2006) showed that there is a higher chance of good level of cross protection between strains with a high level of homology than between strains with a low homology (Figure 1). However, these data also show that the relation is not very strong. Some strains that differ only by a few percentage points from the other strain in the sequenced part of the genome showed a significant drop in cross-protection (Meir et al., 2004; Abdel-Moneim et al., 2006), whereas there was a high level of cross-protection against other strains with a much lower homology (Meir et al., 2004). Figure 1 also shows the wide variation in the level of cross-protection detected in strains with the same level of homology in comparison with the strains that are used as vaccines. Another limitation that needs to be considered is the different parts of $\mathrm{S} 1$ that different laboratories and research groups use for their analyses of level of homology, due to the wide variation of primers used in $P C R$ tests (Figure 2). Several laboratories sequence a part of $\mathrm{S} 1$ that includes the highly variable regions (HVR) 1 and 2; others do not. Analysis of different parts of $\mathrm{S} 1$ can result in different levels of homology. When the IBV strain tested is the result of a recombination event between different IB genotypes, the examination of different parts of S1 may mean the detection of a different genotype (Wang et al., 1993; Jia et al., 1995; Ammayappan et al., 2008; Dolz et al., 2008). The detected homology with other strains is then very dependent on the part of the genome that is being used for the comparisons of the homology. Using larger parts of $\mathrm{S} 1$ for the comparison of strains reduced the risk of finding high levels of homology between strains where there are not.

This leads to the conclusion that genotyping is an excellent tool for epidemiological studies (Figure 3), and that is a convenient, practical tool for typing that best can be used as a screening tool to select potential relevant strains. Especially when there is suspicion in the field that the genotype of recent isolates does not provide accurate information about the true antigenic nature of these IBV isolates, conventional testing (serotyping) and especially in vivo studies are required.

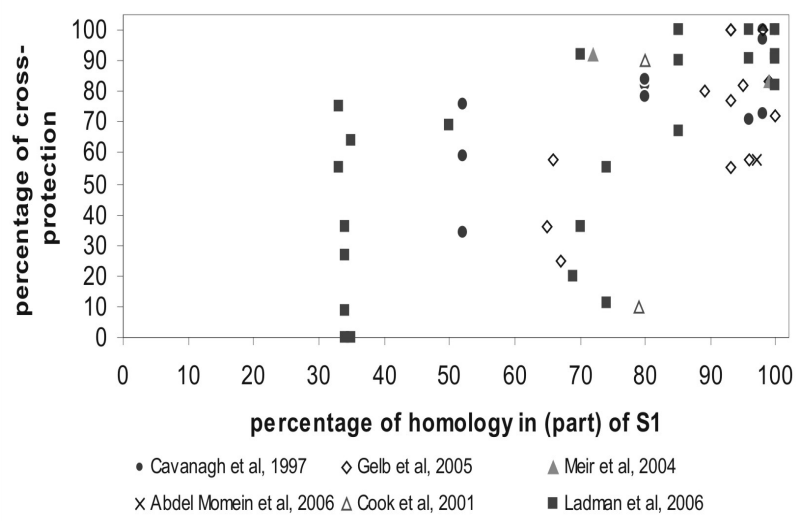

Figure 1 - Correlation between the level of homology in (a part) of the S1 glycoprotein of IBV strains and the level of crossprotection between these strains as reported in six papers.

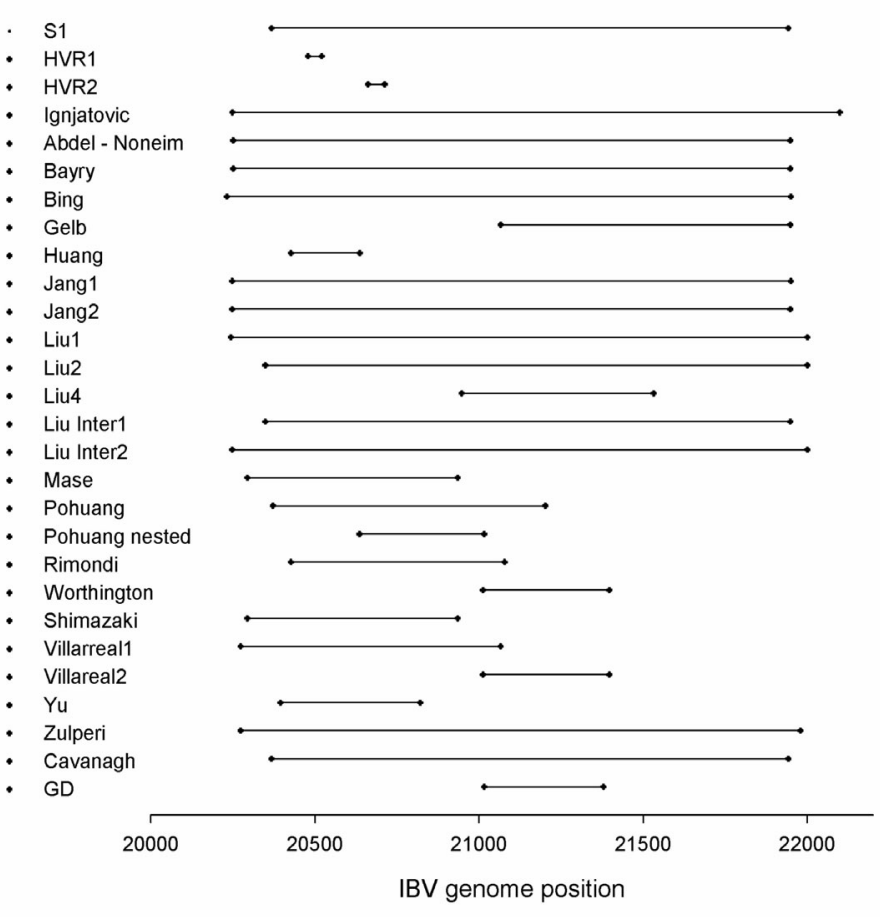

Figure 2 - Examples of sequenced parts (place and length) of the IBV spike protein genome and HVR 1 and 2 used by different authors reporting levels of homology between certain IBV strains or the relation between level of homology between a vaccine and a challenge strain and the detected level of crossprotection. The purpose of this overview is not to compare individual (one or more) primer sets as reported by specific authors but to show the wide variation that is being used in IBV research, which can make it difficult to compare results of different workers, as discussed in this paper. 
Wit JJ (Sjaak) de, Cook JKA, van der Heijden HMJF
Infectious Bronchitis Virus in Asia, Africa, Australia and Latin America - History, Current Situation and Control Measures

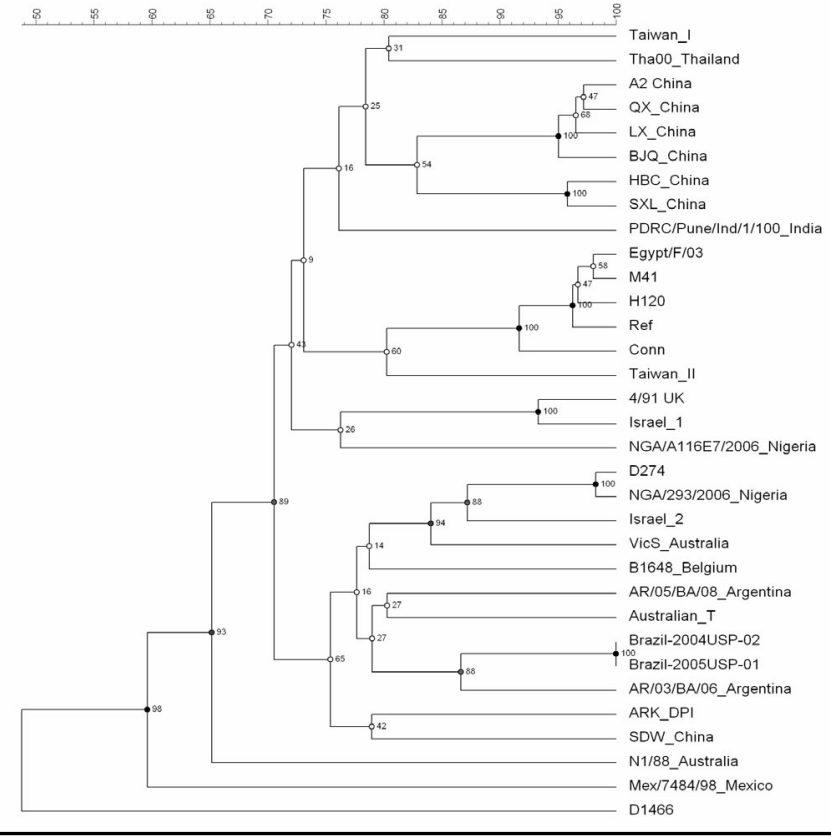

Figure 3 - Phylogenetic tree of a selection of IBV variants from different parts of the world showing the wide diversity of IBV. The tree is based on comparison of the partial $S$ gene (between nucleotides 20447 and 20924 (numbering compared to the genome of Ark DPI (Ammayappan et al, 2008), coding for a part of the S1 glycoprotein including the highly variable regions 1 and 2). The phylogenetic tree analysis was conducted by neighbour-joining method using bootstrap analysis (100 replications). The numbers along the nodes refer to the bootstrap values.

\section{CONTROL MEASURES}

IBV is ubiquitous in most parts of the world where poultry are reared, and it is able to spread very rapidly in non-protected birds (De Wit et al., 1998). It is shed via both the respiratory tract and the faeces and can persist in the birds and faeces for several weeks or months. Although strict biosecurity and working with a one-age system are essential control measures, vaccination is usually essential to increase the resistance of chickens against the challenge with IBV strains (Cook, 2008).

For vaccination of chickens against IBV, both live attenuated and inactivated (usually oil-adjuvanted) vaccines are used. Live vaccines are used particularly in young birds to achieve early protection against challenge, and also for priming of future layers and breeders that are going to be later boosted with the inactivated vaccines. In areas with an increased level of field challenge, live attenuated vaccines are also periodically used during the laying period with the intention of keeping a high level of local protection of the respiratory tract.
Most vaccines used in the world are of the Mass serotype. In several parts of the world, Mass vaccines are the only vaccines allowed, but elsewhere vaccines of one or more other serotypes are permitted. Vaccines of a certain serotype or genotype are normally able to protect well-vaccinated chickens against a homologous challenge. Often, there is partial protection against strains of other protectotypes, serotypes or genotypes that can vary from high to low (Figure 1 and reviewed for the H-strain by Bijlenga et al. (2004). The magnitude and duration of the response to vaccination is dependent on many factors, including age of the chick, levels of maternal immunity, immunogenicity of the vaccine, method of vaccine application, virulence of the field strain challenge, interval between vaccination and challenge, and immunocompetency of the host. Chickens vaccinated under optimal conditions may be immune for many months, and for broilers, this may be life-long (Bijlenga et al., 2004).

It has been shown that vaccination with 2 antigenically distinct live-attenuated vaccines such as Mass and 4/91, can result is a broad cross-protection against many different IBV types (Cook et al., 1999; Terregino et al., 2008). The cross-protection was broader when these vaccines were applied with a 2week interval than when the vaccines were combined on the same day.

Results of challenge studies and field work have shown that vaccination with a bivalent vaccine containing the Mass and Ark strains (Gelb et al., 1989; Gelb et al., 1991; Gelb et al., 2005) provided, in average, higher level of cross-protection against certain heterologous field strains than other combinations of vaccines, such as Mass together with Conn or Mass with JMK. The Mass and Ark vaccine did not provide significant protection against challenge with another strain (Ladman et al., 2002). It is not known whether the separate application of these 2 IBV strains would have resulted in a higher (or lower) level of crossprotection against the same heterologous challenges.

A well-vaccinated chicken is protected against challenge with a virulent homologous IBV strain. This means that this well-vaccinated chicken is also protected against an early revaccination with a homologous vaccine. Neverthelless, revaccination of young birds, especially broilers, using a vaccine of the same serotype as the first vaccine, has proven to be beneficial under field conditions. This is an indication that the quality of the first vaccination may need careful attention. Whatever live vaccine is used, application is a very critical step. IBV is a sensitive virus that can be 
easily inactivated (Cavanagh \& Gelb, 2008), which may produce inadequate vaccination results under field conditions (De Wit et al., 2010). It can be applied by eye- or nasal drop, spray, and drinking water route. It is essential that a high percentage of the birds receive a required dose of the vaccine in the right place. Inadequate uptake of the vaccine may result in no or decreased level of protection, delayed protection, prolonged presence/circulation of the vaccine virus in the flock, resulting in an increased risk of bacterial infections with E.coli or other bacteria (Goren, 1978; Smith et al., 1985; Cook et al., 1986; Matthijs et al., 2003) and even an increase of virulence of the virus (Hopkins \& Yoder, 1986)

In order to achieve higher level of protection of commercial layers and parent stock during the laying period, the use of inactivated IBV vaccines after a priming with live IBV vaccines has been shown to be effective against homologous Mass challenges (Gough et al., 1977; Box et al., 1980; Timms \& Bracewell, 1983). The efficacy of increasing the level of protection against heterologous challenges in the laying period has rarely been reported, although birds that had been vaccinated twice with a live Mass type vaccine and boosted with a killed oil-emulsion vaccine containing a Mass strain showed no protection against challenge with a Ark type strain (Muneer et al., 1987b).

\section{CONCLUSION}

The topic of the how to type the large number of IB variants currently found worldwide and relate this to the best vaccination strategy to use to protect against them is clearly complex. Whilst genotyping has advantages of ease and speed, the number and variety of different primers used by different research groups makes interpretation very difficult, and this paper emphasises the need of a standardised method of performing genotyping. Another major point that needs to be remembered is that only the vaccinated chicken decides whether genetic differences as shown by genotyping or serotyping are relevant for the level of cross-protection.

\section{REFERENCES}

Abdel-Moneim AS, El-Kady MF, Ladman BS, Gelb JJr. S1 gene sequence analysis of a nephropathogenic strain of avian infectious bronchitis virus in Egypt. Virology Journal 2006; 3:78.

Abreu JT, Resende JS, Flatschart RB, Folgueras-Flatschart AV, Mendes AC, Martins NR, Silva CB, Ferreira BM, Resende M. Molecular analysis of Brazilian infectious bronchitis field isolates by reverse transcription-polymerase chain reaction, restriction fragment length polymorphism, and partial sequencing of the $\mathrm{N}$ gene. Avian Diseases 2006; 50:494-501.

Ahmed Z, Naeem K, Hameed A. Detection and seroprevalence of infectious bronchitis virus strains in commercial poultry in Pakistan. Poultry Science 2007; 86:1329-1335.

Alvarado IR, Villegas $P$, Mossos N, Jackwood MW. Molecular characterization of avian infectious bronchitis virus strains isolated in Colombia during 2003. Avian Diseases 2005; 49:494-499.

Ammayappan A, Upadhyay C, Gelb J, Vakharia VN. Complete genomic sequence analysis of infectious bronchitis virus Ark DPI strain and its evolution by recombination. Virology Journal 2008; 5: 157.

Bayry J, Goudar MS, Nighot PK, Kshirsagar SG, Ladman BS, Gelb JJr, Ghalsasi GR, Kolte GN. Emergence of a nephropathogenic avian infectious bronchitis virus with a novel genotype in India. Journal of Clininical Microbiology 2005; 43:916-918.

Bijlenga G, Cook JKA, Gelb JJr, de Wit JJ. Development and use of the $\mathrm{H}$ strain of avian infectious bronchitis virus from the Netherlands as a vaccine: a review. Avian Pathology 2004; 33:550-557.

Bochkov YA, Batchenko GV, Shcherbakova LO, Borisov AV, Drygin VV. Molecular epizootiology of avian infectious bronchitis in Russia. Avian Pathology 2006; 35:379-393.

Boots AM, Benaissa-Trouw BJ, Hesselink W, Rijke E, Schrier C, Hensen EJ. Induction of anti-viral immune responses by immunization with recombinant-DNA encoded avian coronavirus nucleocapsid protein. Vaccine 1992; 10:119-124.

Bourogaa H, Miled K, Gribaa L, El Behi I, Ghram A. Characterization of new variants of avian infectious bronchitis virus in Tunisia. Avian Diseases 2009; 53:426-433.

Box PG, Beresford AV, Roberts B. Protection of laying hens against infectious bronchitis with inactivated emulsion vaccines. Veterinary Record 1980; 106:264-268.

Branden RC, Da Silva EN. Ocurrencia de "nuevos" serotipos de bronquitis infecciosa en Brasil. Proceedings of $6^{\text {th }}$ Seminario Internacional de Patologia Aviar; 1986; Georgia USA.

Callison SA, Jackwood MW, Hilt DA. Molecular characterization of infectious bronchitis virus isolates foreign to the United States and comparison with United States isolates. Avian Diseases 2001; 45:492-499

Cavanagh D, Davis PJ. Coronavirus IBV: removal of spike glycopolypeptide $\mathrm{S} 1$ by urea abolishes infectivity and haemagglutination but not attachment to cells. Journal of General Virology 1986; 67:1443-1448.

Cavanagh D, Gelb Jr. J. Infectious bronchitis. In: Saif YM, Fadly AM, Glisson JR, McDougald, LR, Nolan LK, Swayne DE., editors. Diseases of poultry. 12th ed). lowa: Blackwell Publishing; 2008. p.117-135. 


\section{Wit JJ (Sjaak) de, Cook JKA, van der Heijden HMJF}

Cavanagh D, Davis PJ, Cook JKA, Li D, Kant A, Koch G. Location of the amino acid differences in the S1 spike glycoprotein subunit of closely related serotypes of infectious bronchitis virus. Avian Pathology 1992; 21:33-43.

Cavanagh D, Ellis MM, Cook JKA. Relationship between sequence variation in the S1 spike protein of infectious bronchitis virus and the extent of cross-protection in vivo. Avian Pathology 1997; 26:6374.

Cook JKA. Coronaviridae. In: Pattison M, Bradbury A, editors. Poultry diseases. 6th ed. Amsterdam: Saunders Elsevier; 2008. p. 340-349.

Cook JKA, Smith HW, Huggins MB. Infectious bronchitis immunity: its study in chickens experimentally infected with mixtures of infectious bronchitis virus and Escherichia coli. Journal of General Virology 1986; 67:1427-1434.

Cook JKA, Orbell SJ, Woods MA, Huggins MB. Breadth of protection of the respiratory tract provided by different live-attenuated infectious bronchitis vaccines against challenge with infectious bronchitis viruses of heterologous serotypes. Avian Pathology 1999; 28:477-485.

Cook JKA, Chesher J, Baxendale W, Greenwood N, Huggins MB, Orbell SJ. Protection of chickens against renal damage caused by a nephropathogenic infectious bronchitis virus. Avian Pathology 2001; 30:423-426.

Cubillos A, Ulloa J, Cubillos V, Cook JKA. Characterisation of strains of infectious bronchitis virus isolated in Chile. Avian Pathology 1991; 20:85-99.

Cuiping $X$, Jixun Z, Xudong Z. Isolation and identification of four isolates of infectious bronchitis strains in China and analysis of their SI protein gene. Veterinary Microbiology 2007; 122:61-71.

Cumming RB. Infectious avian nephrosis (uraemia) in Australia. Australian Veterinary Journal 1963; 39:145-147.

De Wit JJ. Detection of infectious bronchitis virus. Avian Pathology 2000; 29:71-93.

De Wit JJ., de Jong MC, Pijpers A, Verheijden JH. Transmission of infectious bronchitis virus within vaccinated and unvaccinated groups of chickens. Avian Pathology 1998; 27:464-471.

De Wit JJ, Swart WAJM, Fabri THF. The efficacy of infectious bronchitis virus vaccinations in the field: association between the $\alpha$-IBV IgM response, protection and vaccine application parameters. Avian Pathology 2010; 39:123-131.

Di Fabio J, Rossini LI, Orbel SJ, Paul G, Huggins MB, Malo A, Silva $B G$, Cook JKA. Characterization of infectious bronchitis viruses isolated from outbreaks of disease in commercial flocks in Brazil. Avian Diseases 2000; 44:582-589.

Dolz R, Pujols J, Ordonez G, Porta R, Majo N. Molecular epidemiology and evolution of avian infectious bronchitis virus in Spain over a fourteen-year period. Virology 2008; 374:50-59.

Ducatez MF, Martin AM, Owoade AA, Olatoye IO, Alkali BR,
Infectious Bronchitis Virus in Asia, Africa, Australia and Latin America - History, Current Situation and Control Measures

Maikano I, Snoeck CJ, Sausy A, Cordioli P, Muller CP. Characterization of a new genotype and serotype of infectious bronchitis virus in Western Africa. Journal of General Virology 2009; 90:2679-2685.

Eid AM. Infectious bronchitis viru-s infection in Egypt. Proceedings of the International Symposium on infectious bronchitis and pneumovirus infections in Poultry; 1998; Rauischholzhausen, Germany. p 145-156.

El-Houadfi M, Jones RC. Isolation of avian infectious bronchitis viruses in Morocco including an enterotropic variant. Veterinary Record 1985; 116:445.

Escorcia M, Jackwood MW, Lucio B, Petrone VM, Lopez C, Fehervari, T, Tellez G. Characterization of Mexican strains of avian infectious bronchitis isolated during 1997. Avian Diseases 2000; 44:944947.

Fabricant J. The early history of infectious bronchitis. Avian Diseases 1998; 42:648-650.

Gelb JJr, Rosenberger JK, Fries PA, Cloud SS, Odor EM, Dohms JE, Jaeger JS. Protection afforded infectious bronchitis virus-vaccinated sentinel chickens raised in a commercial environment. Avian Diseases 1989; 33:764-769.

Gelb JJr, Wolff JB, Moran CA. Variant serotypes of infectious bronchitis virus isolated from commercial layer and broiler chickens. Avian Diseases 1991; 35:82-87.

Gelb JJr, Ladman BS, Tamayo M, Gonzalez M, Sivanandan V. Novel infectious bronchitis virus S1 genotypes in Mexico 1998-1999. Avian Diseases 2001; 45:1060-1063.

Gelb JrJ, Weisman Y, Ladman BS, Meir R. S1 gene characteristics and efficacy of vaccination against infectious bronchitis virus field isolates from the United States and Israel (1996 to 2000). Avian Pathology 2005; 34:194-203.

Goren E. Observations on experimental infection of chicks with Escherichia coli. Avian Pathology 1978; 7:213-224.

Gough RE, Allan WH, Nedelciu, D. Immune response to monovalent and bivalent Newcastle disease and infectious bronchitis inactivated vaccines. Avian Pathology 1997; 6:131-142.

Hesselink WG. Serotyping avain infectious bronchitis virus: selection of a unified method. Proceedings of the International Symposium on Infectious Bronchitis; 1991; Rauischholzhausen, Germany. p. 87-97.

Hidalgo H, Gallardo R, Rosende S. Isolation of infectious bronchitis virus from broiler chickens in Chile. Avian Diseases 1976; 20:601603.

Hidalgo H, Gallardo R, Toro H. Antigenic and pathogenic properties of three isolates of infectious bronchitis virus obtained from vaccinated chickens. Journal of Veterinary Medicine 1986; 33:26-35.

Hipólito O. Isolamento e identificação do virus da bronquite infecciosa das galinhas no Brasil. Arquivo Escola Veterinária Universidade de Minas Gerais 1957; 10:131-151. 


\section{Wit JJ (Sjaak) de, Cook JKA, van der Heijden HMJF}

Hopkins SR, Yoder HWJr. Reversion to virulence of chicken-passaged infectious bronchitis vaccine virus. Avian Diseases 1986: 30:221223.

Huang YP, Lee HC, Cheng MC, Wang CH. S1 and N gene analysis of avian infectious bronchitis viruses in Taiwan. Avian Diseases 2004; 48:581-589.

Huang YP, Wang $\mathrm{CH}$. Development of attenuated vaccines from Taiwanese infectious bronchitis virus strains. Vaccine 2006; 24: 785-791.

Ignjatovic J, Galli U. Immune responses to structural proteins of avian infectious bronchitis virus. Avian Pathology 1995; 24:313332.

Ignjatovic J, Sapats SI, Ashton F. A long-term study of Australian infectious bronchitis viruses indicates a major antigenic change in recently isolated strains. Avian Pathology 1997; 26:535-552.

Ignjatovic J, Gould G, Sapats S. Isolation of a variant infectious bronchitis virus in Australia that further illustrates diversity among emerging strains. Archives of Virology 2006; 151:1567-1585.

Jang JH, Sung HW, Song CS, Kwon HM. Sequence analysis of the S1 glycoprotein gene of infectious bronchitis viruses: identification of a novel phylogenetic group in Korea. Journal of Veterinary Science 2007; 8:401-407.

Jia W, Karaca K, Parrish CR, Naqi SA. A novel variant of avian infectious bronchitis virus resulting from recombination among three different strains. Archives of Virology 1995; 140:259-271.

Jia W, Mondal SP, Naqi SA. Genetic and antigenic diversity in avian infectious bronchitis virus isolates of the 1940s. Avian Diseases 2002; 46:437-441.

Jungherr EL, Chomiak TW, Luginbuhl RE. Immunologic differences in strains of infectious bronchitis virus. Proceedings of the $60^{\text {th }}$ Annual Meeting of the United States Livestock Sanitary Association; 1956; Chicago, USA. p. 203-209.

Klieve AV, Cumming RB. Immunity and cross-protection to nephritis produced by Australian infectious bronchitis viruses used as vaccines. Avian Pathology 1988; 17:829-839.

Koch G, Hartog L, Kant A, van Roozelaar DJ. Antigenic domains on the peplomer protein of avian infectious bronchitis virus: correlation with biological functions. Journal of General Virology 1990; 71: 1929-1935

Ladman BS, Pope CR, Ziegler AF, Swieczkowski T, Callahan CJ, Davison S, Gelb JJr. Protection of chickens after live and inactivated virus vaccination against challenge with nephropathogenic infectious bronchitis virus PAMolgemuth/98. Avian Diseases 2002; 46:938-944.

Ladman BS, Loupos AB, Gelb JJr. Infectious bronchitis virus S1 gene sequence comparison is a better predictor of challenge of immunity in chickens than serotyping by virus neutralization. Avian Pathology 2006; 35:127-133.
Infectious Bronchitis Virus in Asia, Africa, Australia and Latin America - History, Current Situation and Control Measures

Lee EK, Jeon WJ, Lee YJ, Jeong OM, Choi JG, Kwon JH, Choi KS. Genetic diversity of avian infectious bronchitis virus isolates in Korea between 2003 and 2006. Avian Diseases 2008; 52:332-337.

Lee SK, Sung HW, Kwon HM. S1 glycoprotein gene analysis of infectious bronchitis viruses isolated in Korea. Archives of Virology 2004; 149:481-494.

Liu SW, Zhang QX, Chen JD, Han ZX, Liu X, Feng L, Shao YH, Rong $J G$, Kong $X$ G, Tong GZ. Genetic diversity of avian infectious bronchitis coronavirus strains isolated in China between 1995 and 2004. Archives of Virology 2006; 151:1133-1148.

Liu XL, Su JL, Zhao JX, Zhang GZ. Complete genome sequence analysis of a predominant infectious bronchitis virus (IBV) strain in China. Virus Genes 2009; 38:56-65.

Lohr JE. Serologic differences between strains of infectious bronchitis virus from New Zealand, Australia, and the United States. Avian Diseases 1976; 20:478-482.

Lohr JE. Studies on avian infectious bronchitis virus in New Zealand. I. Serotypes. New Zealand Veterinary Journal 1976; 25:48-51.

Lohr JE. Infectious bronchitis in New Zealand, Asia, East Europe. Proceedings of the 1st International Symposium on Infectious Bronchitis; 1988; Rauischholzhausen, Germany. p. 70-75.

Mase M, Tsukamoto K, Imai K, Yamaguchi S. Phylogenetic analysis of avian infectious bronchitis virus strains isolated in Japan. Archives of Virology 2004; 149: 2069-2078.

Mase M, Inoue T, Yamaguchi S, Imada T. Existence of avian infectious bronchitis virus with a European-prevalent 4/91 genotype in Japan. Journal of Veterinary Medical Science 2008; 70:1341-1344.

Matthijs MG, van Eck JH, Landman WJ, Stegeman JA. Ability of Massachusetts-type infectious bronchitis virus to increase colibacillosis susceptibility in commercial broilers: a comparison between vaccine and virulent field virus. Avian Pathology 2003; 32: 473-481.

McFarlane R, Verma R. Sequence analysis of the gene coding for the $\mathrm{S} 1$ glycoprotein of infectious bronchitis virus (IBV) strains from New Zealand. Virus Genes 2008; 37:351-357.

Meir R, Malkinson M, Weisman Y. Characterization of IBV isolates in Israel using RT-PCR and RFLP. Proceedings of the International Symposium on infectious bronchitis and pneumovirus infections in Poultry; 1998; Rauischholzhausen, Germany. p. 229-234.

Meir R, Rosenblut E, Perl S, Kass N, Ayali G, Perk S, Hemsani E. Identification of a novel nephropathogenic infectious bronchitis virus in Israel. Avian Diseases 2004; 48:635-641.

Mockett AP, Cavanagh D, Brown TD. Monoclonal antibodies to the S1 spike and membrane proteins of avian infectious bronchitis coronavirus strain Massachusetts M41. Journal of General Virology $1984 ; 65: 2281-2286$.

Montassier MFS, Brentano L, Montassier HJ, Richtzenhain LJ. Genetic grouping of avain infectious bronchitis virus isolated in Brazil based 


\section{Wit JJ (Sjaak) de, Cook JKA, van der Heijden HMJF}

Infectious Bronchitis Virus in Asia, Africa, Australia and Latin America - History, Current Situation and Control Measures on RT-PCR/RFLP analysis of the $\$ 1$ gene. Pesquisa Veterinaria Brasileira 2008; 28:190-194.

Morley AJ, Thomson DK. Swollen-head syndrome in broiler chickens. Avian Diseases 1984; 28:238-243.

Muneer MA, Newman JA, Goyal SM, Ajmal M. Antibodies to avian infectious bronchitis virus in Pakistani chickens. Poultry Science 1987a; 66:765-767.

Muneer MA, Newman JA, Halvorson DA, Sivanandan V, Coon CN. Effects of avian infectious bronchitis virus (Arkansas strain) on vaccinated laying chickens. Avian Diseases 1987b; 31:820-828.

Pohuang T, Chansiripornchai N, Tawatsin A, Sasipreeyajan J. Detection and molecular characterization of infectious bronchitis virus isolated from recent outbreaks in broiler flocks in Thailand. Journal of Veterinary Science 2009; 10:219-223.

Rimondi A, Craig MI, Vagnozzi A, Konig G, Delamer M, Pereda A. Molecular characterization of avian infectious bronchitis virus strains from outbreaks in Argentina (2001-2008). Avian Pathology 2009; 38:149-153.

Roussan DA, Totanji WS, Khawaldeh GY. Molecular subtype of infectious bronchitis virus in broiler flocks in Jordan. Poultry Science 2008; 87:661-664.

Seyfi Abad Shapouri MR, Mayahi M, Assasi K, Charkhkar S. A survey of the prevalence of infectious bronchitis virus type 4/91 in Iran. Acta Veterinaria Hungarica 2004; 52:163-166.

Sheble A, Sabry MZ, Davelaar FG, Burger AG, Khafagy AR, Moustafa MM, Henna M. Present status of infectious bronchitis in Egypt. Journal of the Egyptian Veterinary Medical Association 1986; 46: 393-411.

Shieh HK, Shien JH, Chou HY, Shimizu Y, Chen JN, Chang PC. Complete nucleotide sequences of $\mathrm{S} 1$ and $\mathrm{N}$ genes of infectious bronchitis virus isolated in Japan and Taiwan. Journal of Veterinary Medical Science 2004; 66:555-558.

Shimazaki Y, Horiuchi T, Harada M, Tanimura C, Seki Y, Kuroda Y, Yagyu K, Nakamura S, Suzuki S. Isolation of 4/91 type of infectious bronchitis virus as a new variant in Japan and efficacy of vaccination against 4/91 type field isolate. Avian Diseases 2008; 52:618-622.

Smith HW, Cook JKA, Parsel ZE. The experimental infection of chickens with mixtures of infectious bronchitis virus and Escherichia coli. Journal of General Virology 1985; 66:777-786.

Song CS, Lee YJ, Kim JH, Sung HW, Lee CW, Izumiya Y, Miyazawa T, Jang HK, Mikami T. Epidemiological classification of infectious bronchitis virus isolated in Korea between 1986 and 1997. Avian Pathology 1998; 27:409-416.

Terregino C, Toffan A, Beato MS, De Nardi R, Vascellari M, Meini A, Ortali G, Mancin M, Capua I. Pathogenicity of a QX strain of infectious bronchitis virus in specific pathogen free and commercial broiler chickens, and evaluation of protection induced by a vaccination programme based on the Ma5 and 4/91 serotypes. Avian Pathology 2008; 37:487-493.
Timms LM, Bracewell CD. Cell mediated and humoral immune response of chickens to inactivated oil-emulsion infectious bronchitis vaccine. Research in Veterinary Science 1983; 34:224230.

Villarreal LY, Brandao PE, Chacon JL, Assayag MS, Maiorka PC, Raffi $P$, Saidenberg $A B$, Jones $R C$, Ferreira AJ. Orchitis in roosters with reduced fertility associated with avian infectious bronchitis virus and avian metapneumovirus infections. Avian Diseases 2007a; 51: 900-904.

Villarreal LY, Brandao PE, Chacon JL, Saidenberg AB, Assayag MS, Jones RC, Ferreira AJ. Molecular characterization of infectious bronchitis virus strains isolated from the enteric contents of Brazilian laying hens and broilers. Avian Diseases 2007b; 51:974-978.

Wang $\mathrm{CH}$, Huang YC. Relationship between serotypes and genotypes based on the hypervariable region of the $\mathrm{S1}$ gene of infectious bronchitis virus. Archives of Virology 2000; 145:291300.

Wang $\mathrm{CH}$, Tsai $\mathrm{CT}$. Genetic grouping for the isolates of avian infectious bronchitis virus in Taiwan. Archives of Virology 1996; 141:1677-1688.

Wang L, Junker D, Collisson EW. Evidence of natural recombination within the S1 gene of infectious bronchitis virus. Virology 1993; 192:710-716.

Wei PLM, Wei ZJ, Wang XY, Mo ML, Chen QY. Genotyping and serotyping of Guangxi IBV isolates during 1985-2008. Proceedings of the $6^{\text {th }}$ International Symposium on Avian Corona- and Pneumoviruses and Complicating Pathogens; 2009; Rauischholzhausen, Germany. p. 59-66.

Wu ZQ, Yang QW, Fu C, Zhao XY, Ignjatovic J. Antigenic and immunogenic characterization of infectious bronchitis virus strains isolated in China between 1986 and 1995. Avian Pathology 1998; 27:578-585.

Yu L, Wang Z, Jiang Y, Low S, Kwang J. Molecular epidemiology of infectious bronchitis virus isolates from China and Southeast Asia. Avian Diseases 2001; 45:201-209.

Zulperi ZM, Omar AR, Arshad SS. Sequence and phylogenetic analysis of S1, S2, M, and $\mathrm{N}$ genes of infectious bronchitis virus isolates from Malaysia. Virus Genes 2009; 38:383-391. 